\title{
Pretransplant serum ferritin level may be a predictive marker for outcomes in patients having undergone allogeneic hematopoietic stem cell transplantation
}

\author{
S. SIVGIN ${ }^{1}$, S. BALDANE 2 , L. KAYNAR ${ }^{1}$, F. KURNAZ ${ }^{1}$, C. PALA ${ }^{1}$, H. SIVGIN ${ }^{3}$, A. OZTURK ${ }^{4}$, M. CETIN ${ }^{1}$, A. UNAL ${ }^{1}$, B. ESER ${ }^{1}$ \\ ${ }^{1}$ Dedeman Stem Cell Transplantation Hospital, Department of Hematology; ${ }^{2}$ Department of Internal Medicine; ${ }^{3}$ Department of Medical Genetics; \\ ${ }^{4}$ Department of Biostatistics, Faculty of Medicine, Erciyes University, Kayseri, Turkey
}

*Correspondence: serdarsvgn@gmail.com

Received September 13, 2011 / Accepted October 5, 2011

\begin{abstract}
Iron overload increases the risk of infections, veno-occlusive disease and hepatic dysfunction in post-transplant period. Our objective was to investigate the association of pre-transplant ferritin levels with complications and survival after allogeneic hematopoietic stem cell transplantation (alloHSCT).

We retrospectively analysed 84 patients' data who had undergone allogeneic HSCT into two groups: patients with a serum ferritin level $\geq 1000 \mathrm{ng} / \mathrm{ml}$, and patients with $<1000 \mathrm{ng} / \mathrm{ml}$ at the time of HSCT.

Cox-regression analysis showed that pre-transplant serum ferritin levels were significantly higher in patients who had at least one infectious event compared with those who had no any infectious event in the post-transplant 100 days $(\mathrm{p}<0.023)$. Overall survival (OS) and disease-free survival (DFS) rates were significantly higher in patients with a time-to-tx interval $<12$ months compared with group time-to-tx interval $>12$ months $(\mathrm{p}=0.002$ and $\mathrm{p}=0.008$ respectively). A higher risk of death was observed in high-ferritin group (hazard ratio=2.27, CI:1.01-5.09, $\mathrm{p}=0.023$ for OS and hazard ratio=2.49, CI:1.12-5.53 $\mathrm{p}=0.039$ for DFS). No significant effect on OS and DFS among groups was observed for variables conditioning regimen, gender and diagnosis. Acute GVHD was more common in patients with a ferritin level $\geq 1000 \mathrm{ng} / \mathrm{mL}$, but this was not statistically significant ( $p>0.05$ ). There was no statistical significance in both groups (ferritin $\geq 1000 \mathrm{ng} / \mathrm{mL}$ and ferritin $<1000 \mathrm{ng} / \mathrm{mL}$ ) for relapse rates $(\mathrm{p}>0.05)$. Platelet and neutrophil engaftment day was not found statistically significant compared with both groups ( $\mathrm{p}=0.273$ and $\mathrm{p}=0.882$, respectively).

Pre-transplant ferritin levels may predict poor outcomes in patients who had undergone allogeneic hematopoietic stem cell transplantation.
\end{abstract}

Key words: allogeneic hematopoietic stem cell transplantation, ferritin, graft-versus-host disease, iron overload, survival

Allogeneic hematopoietic stem cell transplantation (alloHSCT) is considered a curative treatment for various hematologic malignancies. Although improvement of the outcome has been achieved in recent decades via advances in many procedures, such as the prevention of graft-versus-host disease (GVHD), infectious complications remain an important contributor to transplant-related mortality $[1,2]$. It has recently been reported that iron overload increases the risk of veno-occlusive disease, hepatic dysfunction, and infections after transplantation [3]. It has also been shown that elevated serum levels of pre-transplant ferritin, which is a reliable marker of iron overload, are associated with increased nonrelapse mortality in patients having undergone allo-HSCT [4-6]. The pathogenetic mechanisms for iron overload in hematological malignancies are: prolonged dyserythropoiesis, hemolysis, increased intestinal iron absorption, and multiple red blood cell transfusions [7]. Free iron causes increased sensitivity for infections by inhibiting chemotaxis and phagocytosis and also impaires cellular immunity [8]. Excessive amounts of iron can cause tissue damage, resulting in protein oxidation, membrane lipid peroxidation, and nucleic acid modification, with conversion of hydrogen peroxide to reactive oxygen species [9]. Due to the fact that ferritin is an acute phase reactant, it may not always show total iron body stores reliably. However, it is the most common and cost-effective commercial method for measuring the total body iron. Stem cell transplant patients are at risk of excess accumulation of iron resulting from repeated blood transfusions both before and during transplantation 
[10]. In this study we aimed to evaluate the influence of pretransplantation ferritin levels on the outcomes of alloHSCT recipients, including graft-versus-host disease (GVHD), infections and survival.

\section{Patients and Methods}

A total of 211 patients who had undergone alloHSCT between April 2004 and June 2010 at Dedeman Stem Cell Transplantation Hospital, Faculty of Medicine, Erciyes University, Kayseri, Turkey; were analysed retrospectively. The data was obtained from the patients' records. A pretransplantation serum ferritin level (drawn within 100 days prior to transplantation) was available for 84 patients. The patients were divided into two groups; patients with a pre-transplant ferritin level lower than $1000 \mathrm{ng} / \mathrm{ml}$ (ferritin $<1000 \mathrm{ng} / \mathrm{ml}$ ) and higher than $1000 \mathrm{ng} / \mathrm{ml}$ (ferritin $\geq 1000 \mathrm{ng} / \mathrm{ml}$ ). Graft-vs-host disease (GvHD) was graded according to European Blood and Marrow Transplantation criteria [11]. Engraftment was defined, for platelet engrafment, as the day on which platelet count exceeds $20000 / \mathrm{mm}^{3}$ and the day on which neutrophil count exceeds $500 / \mathrm{mm}^{3}$ for at least 3 days consecutively for neutrophil engraftment. This study was approved by the local ethic committee of Erciyes University.

Statistical analysis. Continuous variables between the 2 groups were compared using the Mann-Whitney test. Categorical variables were compared using the $\chi^{2}$ test. Overall survival (OS) and disease free-survival (DFS) were calculated using the Kaplan-Meier method. Possible risk factors were tested using the log rank test and the Cox regression model. The calculations were performed using commercially available software (SPSS version 18.0; SPSS Inc, Chicago, Illinois). Numerical variables are summarized by their medians and ranges, categorical variables by counts and relative frequencies. The primary end-points were overall survival (OS) and disease-free survival (DFS). OS was defined as the time between transplantation and death (from any cause) or last follow-up. Univariate and multivariate survival analyses were performed using Cox proportional hazards regression to identify the most significant independent prognostic factors.

\section{Results}

A total of 84 patients who underwent alloHSCT were retrospectively investigated. 41 (48.8\%) of the patients were female, and $43(51.2 \%)$ were male. The majority of the patients was diagnosed with AML $(37,44.1 \%)$, while the others were ALL (16, 19.1\%), aplastic anemia (16, 19.1\%), non-Hodgkin lymphoma (5,5.8\%), chronic myelogenous leukemia $(2,2.3 \%)$, and others $(8,9.6 \%)$. The median age was found to be 28 years (min-max:15-56). The patient characteristics are shown in Table 1. The conditioning regimen was $\mathrm{Bu} / \mathrm{Cy}$ in 43 (51.1\%) of the patients, Cy / TBI in 13 (15.4\%), ATG/Flu/Cy in 13 (15.4\%), ATG/Flu/Bu in $7(8.4 \%)$ and Flu / Bu in $2(2.3 \%)$ of the patients. The median number of RBC transfusions in the pre-transplant period was $6(2-13)$. The iron parameters and albumin levels of the patients are shown in Table 2.

GVHD and relapse. A total of 44 patients were diagnosed with GVHD. Of these patients, 18 had acute GVHD (21.4\%) and 26 had chronic GVHD (30.9\%). The site of acute GVHD was the liver in 7 patients (38.8\%), skin in 5 patients (27.7\%) and gastrointestinal tract in 6 patients (33.3\%). The distrubution of sites of chronic GVHD were liver in 12 patients (46.1\%), skin in 9 patients (34.6\%) and GI tract in 5 patients (19.2\%). Acute GVHD was more common in patients with a ferritin level $>1000 \mathrm{ng} / \mathrm{mL}$, but this was not statistically significant $(p>0.05)$. There was no statistical significance between groups ferritin $>1000 \mathrm{ng} / \mathrm{mL}$ and ferritin $\geq 1000 \mathrm{ng} / \mathrm{mL}$ for chronic GVHD ( $\mathrm{p}>0.05)$.

In relapse analysis, a total of $18(21.4 \%)$ patients relapsed after transplantation. Of the patients who relapsed, $13 \mathrm{had}$ acute leukemia (72.2\%), 3 non-Hodgkin lymphoma (16.6\%), one patient multiple myeloma (5.6\%) and one aplastic anemia (5.6\%). There was no statistical significance in both ferritin groups (ferritin $\geq 1000 \mathrm{ng} / \mathrm{mL}$ and ferritin $<1000 \mathrm{ng} / \mathrm{mL}$ ) for relapse rates $(\mathrm{p}>0.05)$.

Infectious events. In our study, cox-regression analysis showed that pre-transplant serum ferritin levels were significantly higher in patients who had had at least one infectious event, as was the case in 51 patients (60.7\%), compared with those who had not had any infectious event in the 100 posttransplant days $(\mathrm{p}<0.023)$. Most of these infectious events were pneumonia (29 patients, 56.8\%), diarrhea $(7,13.7 \%)$, bacteremia $(14,27.4 \%)$, mucositis $(11,21.5 \%)$, perianal abscess $(5,9.8 \%)$ and zona zoster in one (1.9\%). Fungal pneumonia was diagnosed in 23 of 29 patients $(79.3 \%)$ in the post-transplant period, with the remaining cases $(6$ patients, 20.7\%) having a bacterial origin. Pre-transplant serum ferritin levels were found to be significantly higher in patients who had experienced an infectious event $(\mathrm{p}<0.05)$. In patients with fungal pneumonia, median ferritin level was found to be $1815 \mathrm{ng} / \mathrm{ml}$ (min-max: 20-6418), while in patients without a history of fungal pneumonia median level was found to be $905 \mathrm{ng} / \mathrm{ml}$ (min-max: 18-9513). The difference between groups with and without pneumonia was statistically significant $(\mathrm{p}<0.005)$.

Effect of ferritin on peritransplant mortality. Peritransplant mortality was defined as death within 3 months of transplant. A total of 6 of the 84 patients $(7.1 \%)$ died within 100 days of alloHSCT. Univariate analysis showed that all of deaths occurred from among the high-ferritin $(\geq 1000 \mathrm{ng} / \mathrm{mL})$ group. In the high-ferritin group, 6 of 51 patients died (11.7\%), but no death was observed from among the 33 patients of the low-ferritin group $(<1000 \mathrm{ng} /$ $\mathrm{mL}, 0 \%)$. Though all deaths were from among high-ferritin group, the difference between groups was not statistically significant $(\mathrm{p}=0.077)$ for peritransplant mortality. In our study, we showed that elevated pre-transplantation serum ferritin levels were significantly associated with increased rates of infectious events, including pneumonia, decreased 
Table 1. Patient characteristics

\begin{tabular}{|c|c|c|c|}
\hline & $\begin{array}{c}\text { Ferritin< }<1000 \mathrm{ng} / \mathrm{mL}(33) \\
\mathrm{N} \%\end{array}$ & $\begin{array}{c}\text { Ferritin } \geq 1000 \mathrm{ng} / \mathrm{mL}(51) \\
\mathrm{N} \%\end{array}$ & $\begin{array}{c}\text { Total }(84) \\
\text { N \% }\end{array}$ \\
\hline \multicolumn{4}{|l|}{ Age } \\
\hline Median (min-max) & $29(15-56)$ & $27(18-59)$ & $28(15-56)$ \\
\hline mean & 45 & 40 & 29 \\
\hline \multicolumn{4}{|l|}{ Gender } \\
\hline male & $17(51.5)$ & $26(50.9)$ & $43(51.2)$ \\
\hline female & $16(48.5)$ & 25 (49.1) & $41(48.8)$ \\
\hline \multicolumn{4}{|l|}{ Diagnosis } \\
\hline$A M L$ & $11(33.3)$ & $26(50.9)$ & $37(44.1)$ \\
\hline$A L L$ & $3(9.1)$ & $13(25.6)$ & $16(19.1)$ \\
\hline$C M L$ & $2(6.0)$ & 0 & $2(2.3)$ \\
\hline$A A$ & $6(18.1)$ & $10(19.7)$ & $16(19.1)$ \\
\hline NHL & $4(12.1)$ & $1(1.9)$ & $5(5.8)$ \\
\hline Others & $7(21.2)$ & $1(1.9)$ & $8(9.6)$ \\
\hline \multicolumn{4}{|c|}{ Median interval to tx (months) } \\
\hline$<12$ months & $23(69.7)$ & $35(68.7)$ & $58(69.1)$ \\
\hline$>12$ months & $10(30.3)$ & $16(31.3)$ & $26(30.9)$ \\
\hline \multicolumn{4}{|l|}{ Graft source } \\
\hline PBSC & $33(100)$ & $51(100)$ & $84(100)$ \\
\hline$B M$ & 0 & 0 & 0 \\
\hline \multicolumn{4}{|l|}{ Donor status } \\
\hline Sibling & $31(93.9)$ & $50(98.2)$ & $81(96.4)$ \\
\hline Haploidentical & $2(6.1)$ & $1(1.8)$ & $3(3.6)$ \\
\hline Unrelated & 0 & 0 & 0 \\
\hline $\mathrm{CD}^{+} 4^{+}\left(10^{6} / \mathrm{kg}\right)$ & $6.7(4-19)$ & $6.4(3-14)$ & \\
\hline \multicolumn{4}{|l|}{ Preparative regimen } \\
\hline$C y / B u$ & $15(45.5)$ & $26(50.9)$ & $41(48.8)$ \\
\hline$C y / T B I$ & $3(9.1)$ & $10(19.7)$ & $13(15.4)$ \\
\hline$A T G / F l u / C y$ & $7(21.2)$ & $7(13.8)$ & $14(16.7)$ \\
\hline Others & $8(24.2))$ & $8(15.6)$ & $16(19.1)$ \\
\hline \multicolumn{4}{|l|}{ HLA match } \\
\hline full-match & $27(81.8)$ & $44(86.2)$ & $71(84.5)$ \\
\hline$\geq 1$ miss-match & $6(18.2)$ & $7(13.8)$ & $13(15.5)$ \\
\hline
\end{tabular}

Table 2. Serum iron status and albumin

\begin{tabular}{lccc}
\hline Variables & $\begin{array}{c}\text { Ferritin }(<1000 \mathrm{ng} / \mathrm{mL}) \\
\mathrm{N}=33(39.2 \%) \\
\text { median }(\text { min-max })\end{array}$ & $\begin{array}{c}\text { Ferritin }(\geq 1000 \mathrm{ng} / \mathrm{mL}) \\
\mathrm{N}=51(60.8 \%) \\
\text { median }(\min -\mathrm{max})\end{array}$ \\
\hline Ferritin $(\mathrm{ng} / \mathrm{ml})$ & $388.6(18-905)$ & $1705.0(1021-9513)$ & $\mathrm{P}$ \\
Serum iron $(\mu \mathrm{g} / \mathrm{dL})$ & $95.0(30-303)$ & $172.0(30-396)$ & $<\mathbf{0 . 0 0 1}$ \\
Total iron binding capacity $(\mu \mathrm{g} / \mathrm{dL})$ & $264.0(111-401)$ & $270.0(18-692)$ & $\mathbf{0 . 0 0 4}$ \\
Transferrin saturation $(\%)$ & $40.4(13.8-97.5)$ & $75.4(5.9-100)$ & 0.916 \\
Albumin $(\mathrm{g} / \mathrm{dl})$ & $3.9(2-4.8)$ & $3.7(1.6-4.8)$ & 0.052 \\
\hline
\end{tabular}

disease-free survival (DFS) and overall survival (OS), as shown in Figures 1 and 2.

Effect of time-to-transplant interval on survival. The patients were divided into two groups according to time interval from diagnosis to transplantation (tx). One group comprised patients who had undergone alloHSCT before or within 12 months from diagnosis ( $<12$ months; early tx) and the other group of those who had undergone alloHSCT more than 12 months from diagnosis ( $>12$ months; late tx). The results of cox regression analysis showed that both overall survival (OS) and disease-free survival (DFS) rates were significantly higher in patients with a time-to-tx interval $<12$ months compared with the group time-to-tx interval $>12$ months $(\mathrm{p}=0.002$ and $\mathrm{p}=0.008$ respectively). The median survival in early transplant group was found to be 68 months (min-max; 34-101 months) and in late tx group 26 months ( min-max; 12-52 months). 


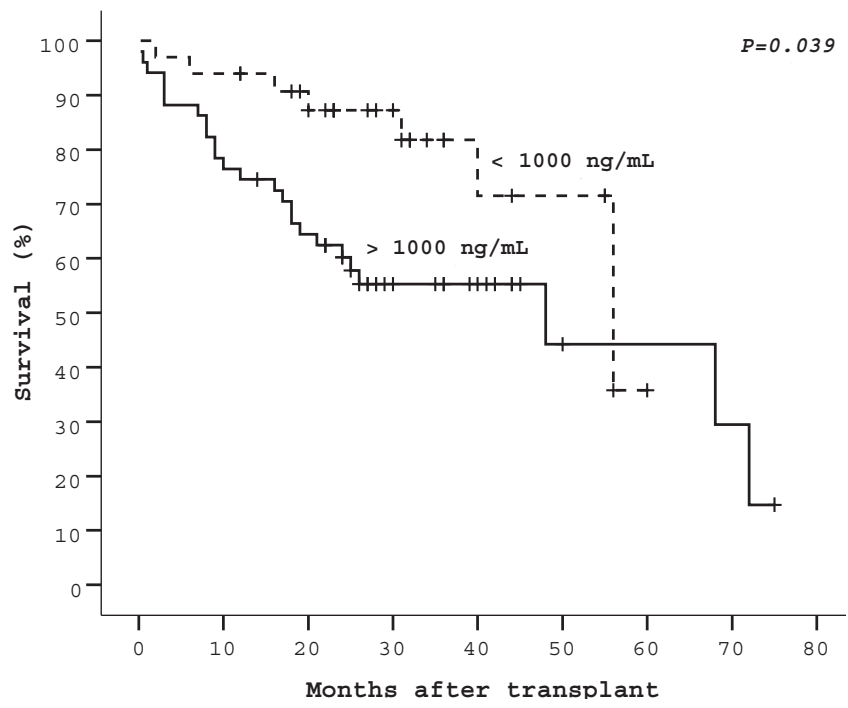

Figure 1. Disease-free survival (DFS) analysis for ferritin levels

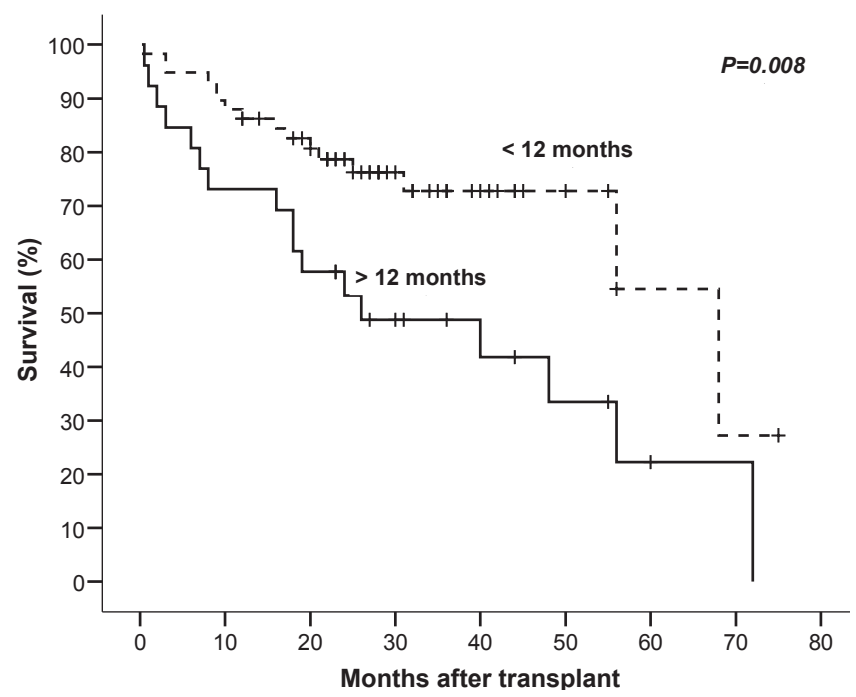

Figure 3. Disease-free survival (DFS) analysis for time-to-transplant intervals

There was a strong association between survival rates and time-to-tx interval. Patients who underwent alloHSCT before or within 12 months from diagnosis, OS and DFS were found to be longer than patients whom underwent alloHSCT longer than 12 months from diagnosis (Figures 3 and 4).

Engraftment. The median day for platelet engraftment was found to be 10.5 days (min-max: 8.0-39.0) in group ferritin $<1000 \mathrm{ng} / \mathrm{ml}$ and 11.5 days (7.0-30.0) in group ferritin $\geq 1000 \mathrm{ng} / \mathrm{ml}$. The difference was not statistically significant $(\mathrm{p}=0.273)$. The median day for neutrophil engraftment was found to be 14.5 days (8.0-39.0) in group ferritin< $1000 \mathrm{ng} /$ $\mathrm{ml}$ and 14.0 days $(9.0-30.0)$ in group ferritin $\geq 1000 \mathrm{ng} / \mathrm{ml}$.

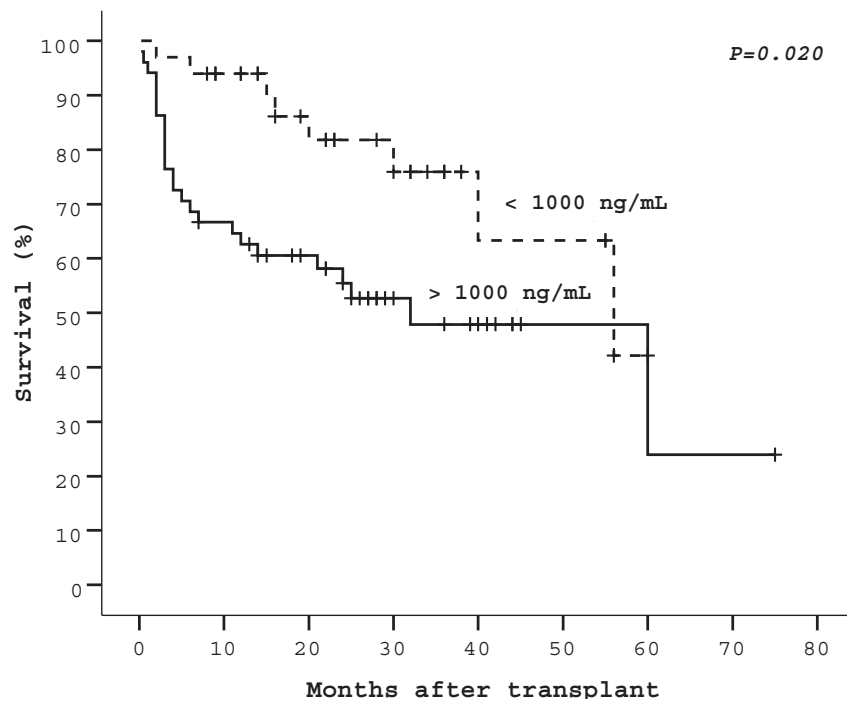

Figure 2. Overall survival (OS) analysis for ferritin levels

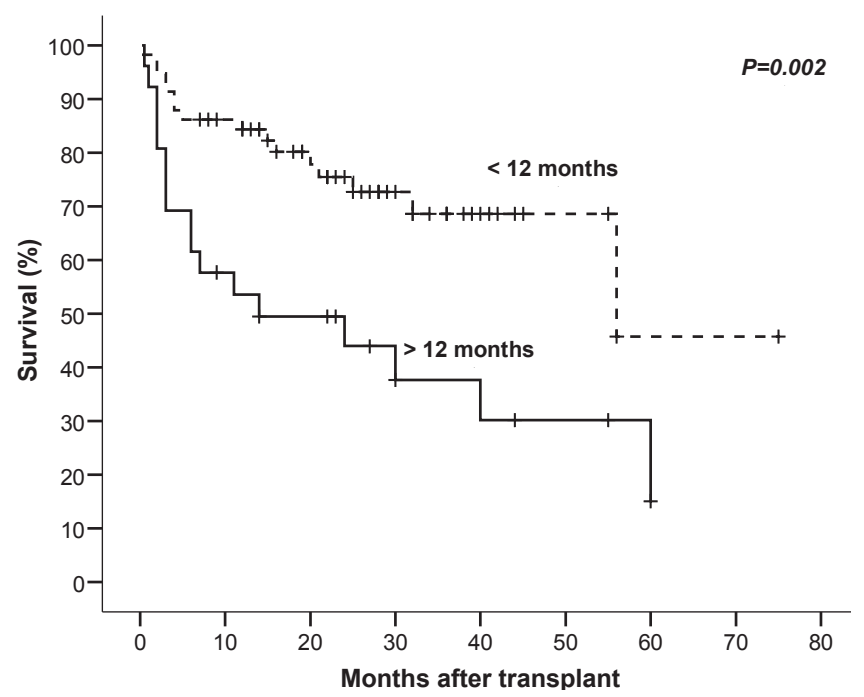

Figure 4. Overall survival (OS) analysis for time-to-transplant intervals

This difference was not statistically significant $(\mathrm{p}=0.882)$. In general estimation, ferritin levels had no effect on both platelet and neutrophil engraftment. The data are shown in Table 3.

Overall survival (OS) and Disease-free survival (DFS) relation with ferritin. A total of 6 patients (18.1\%) died in the first 100 days of transplantation and 27 patients $(81.9 \%)$ died after completing 100 days. Univariate and multivariate analysis showed that high pre-transplant ferritin levels $(\geq 1000 \mathrm{ng} / \mathrm{mL})$ were correlated with decreased overall survival (OS) and disease-free survival (DFS) rates compared with lower pre-transplant ferritin levels $(<1000 \mathrm{ng} / \mathrm{ml})$ $(p=0.03$ and $p=0.02$ respectively). A higher risk of death 
Table 3. Comparison of parameters affecting post-transplant outcomes in alloHSCT recipients

\begin{tabular}{|c|c|c|c|}
\hline Variables & $\begin{array}{l}\text { Ferritin }(<1000 \mathrm{ng} / \mathrm{mL}) \\
\text { median }(\min -\max )\end{array}$ & $\begin{array}{l}\text { Ferritin }(\geq 1000 \mathrm{ng} / \mathrm{mL}) \\
\text { median }(\min -\max )\end{array}$ & $\mathbf{P}$ \\
\hline Platelet engraftment (day) & $10.5(8.0-39.0)$ & $11.5(7.0-30.0)$ & 0.273 \\
\hline \multirow[t]{2}{*}{ Neutrophil engraftment (day) } & $14.5(8.0-39.0)$ & $14.0(9.0-30.0)$ & 0.882 \\
\hline & $\mathrm{N}(\%)$ & $\mathrm{N}(\%)$ & \\
\hline \multicolumn{4}{|l|}{ Infection } \\
\hline No & $15(71.4)$ & $6(28.6)$ & 0.001 \\
\hline Yes & $18(28.6)$ & $45(71.4)$ & \\
\hline \multicolumn{4}{|l|}{ Acute GVHD } \\
\hline No & $28(42.4)$ & $38(57.6)$ & 0.291 \\
\hline Yes & $5(27.8)$ & $13(72.2)$ & \\
\hline \multicolumn{4}{|l|}{ Chronic GVHD } \\
\hline No & $20(35.7)$ & $36(64.3)$ & 0.355 \\
\hline Yes & $13(46.4)$ & $15(53.6)$ & \\
\hline \multicolumn{4}{|l|}{ Relapse } \\
\hline No & $28(42.4)$ & $38(57.6)$ & 0.291 \\
\hline Yes & $5(27.8)$ & $13(72.2)$ & \\
\hline \multicolumn{4}{|l|}{ Exitus } \\
\hline No & $25(49.0)$ & $26(51.0)$ & 0.039 \\
\hline Yes & $8(24.2)$ & $25(75.8)$ & \\
\hline
\end{tabular}

Bold values are statistically significant

was observed in high-ferritin group (hazard ratio $=2.27$, CI:1.01-5.09, $\mathrm{p}=0.023$ for OS and hazard ratio=2.49, CI:1.12$5.53 \mathrm{p}=0.039$ for DFS), among patients with a time -to-tx interval longer than 12 months (hazard ratio $=2.45, \mathrm{CI}: 1.23$ 4.87, $\mathrm{p}=0.02$ for OS and hazard ratio $=2.78, \mathrm{CI}: 1.39-5.54$, $\mathrm{p}=0.008$ for $\mathrm{DFS}$ ), in patients with $\geq 1$ mismatch (hazard ratio $=2.48$, CI: $1.10-5.58, \mathrm{p}=0.023$ for OS and hazard ratio:2.61, CI:1.16-5.88, $\mathrm{p}=0.021$ for DFS) and patients with infection (hazard ratio: $2.92, \mathrm{p}=0.046$ for OS and hazard ratio: $2.88, \mathrm{CI}$ : 1.02-8.36, $\mathrm{p}=0.049$ for DFS). No significant effect on OS and DFS among groups was observed for variables conditioning regimen, number of $\mathrm{CD}_{3} 4^{+}\left(10^{6} / \mathrm{kg}\right)$, gender and diagnosis. The results are shown in Table 4 .

\section{Discussion}

This study was mainly focused on the predictive role of pretransplantation serum ferritin levels on outcomes of patients having undergone alloHSCT in the post-transplant period.

Recent studies have suggested a marked relationship between iron overload and toxic and infectious complications in the early post-HSCT period in alloHSCT recipients, which indicates the effect of iron burden on mucositis, bacteremia, and fever [12,13]. Iron overload has been associated with increased susceptibility to organ damage and increased risk of infection $[14,15]$. Patients undergoing HSCT often have received multiple blood transfusions prior to transplantation, which probably contribute to elevated ferritin levels. Recently, iron overload has been shown to increase the toxic effects of conditioning regimens in HSCT recipients.
Elevated levels of pre-transplant ferritin were found to be associated with increased rates of fungal infections in alloHSCT recipients $[16,17]$. In our patients, there was a remarkable association between serum ferritin levels and infectious events, including pneumonia, of which the majority had a fungal origin. In iron overload states, increased availability of iron provides an important nutrient for both bacterial and fungal growth, and this may impair the host defense. There is a positive correlation between iron overload and infectious events in both allogeneic and autologous hematopoietic stem cell transplantation. Among these infections, bacteremia, invasive aspergillosis and mucormycosis are the most prevalent [18].

Kataoka et al [19] showed in a study of 264 patients who underwent alloHSCT that patients with high levels of ferritin prior to the transplantation had lower overall survival, and higher nonrelapse mortality. Also, these patients were found to be more likely to die due to infections and organ failure.

Patients who undergo alloHSCT often have history of multiple red blood cell (RBC) transfusions during chemotherapy prior to transplantation. This may give rise to elevated levels of ferritin in body stores. In our patients, it was not possible to obtain clear information about transfusions. Increased amounts of ferritin in body stores severely damage or abolish normal bactericidal mechanisms, leading to overwhelming growth of bacteria and fungi [20]. Iron does not only adversely affect the phagocytic, chemotactic, and bactericidal capacity of neutrophils and monocytes, but also inhibits the activity of natural killer cells and macrophages [21].

The data suggest that, in patients with thalassemia, iron overload causes deaths which are mainly due to cardiomyopa- 
Table 4. Univariate and multivariate prognostic factors for overall survival (OS) and disease-free survival (DFS) in alloHSCT recipients

\begin{tabular}{|c|c|c|c|c|}
\hline \multirow{2}{*}{ Variable } & \multicolumn{2}{|c|}{ OS } & \multicolumn{2}{|c|}{ DFS } \\
\hline & Univariate & Multivariate & Univariate & Multivariate \\
\hline & HR (\%95 CI) & HR (\%95 CI) & HR (\%95 CI) & HR (\%95 CI) \\
\hline \multicolumn{5}{|l|}{ Ferritin } \\
\hline$<1000$ & 1.00 & 1.00 & 1.00 & 1.00 \\
\hline$\geq 1000$ & $2.27(1.01-5.09)$ & $2.46(1.10-5.52)$ & $2.49(1.12-5.53)$ & $2.96(1.32-6.62)$ \\
\hline Age & $1.01(0.97-1.04)$ & NS & $1.00(0.97-1.04)$ & - NS \\
\hline \multicolumn{5}{|l|}{ Gender } \\
\hline Male & 1.00 & - NS & 1.00 & - NS \\
\hline Female & $1.00(0.50-1.99)$ & - NS & $1.07(0.54-2.13)$ & - NS \\
\hline \multicolumn{5}{|l|}{ Infection } \\
\hline Yes & 1.00 & - NS & 1.00 & - NS \\
\hline No & $2.92(1.02-8.36)$ & - NS & $2.88(1.00-8.26)$ & - \\
\hline \multicolumn{5}{|l|}{ Donor status } \\
\hline Gender match & 1.00 & - NS & 1.00 & - \\
\hline Gender mismatch & $0.85(0.41-1.77)$ & - NS & $0.99(0.48-2.04)$ & - \\
\hline \multicolumn{5}{|l|}{ Diagnosis } \\
\hline 1 & 1.00 & - NS & 1.00 & - \\
\hline 2 & $1.81(0.77-4.25)$ & - NS & $1.76(0.75-4.10)$ & - \\
\hline 3 & $1.93(0.69-5.41)$ & - NS & $1.37(0.51-3.71)$ & - \\
\hline 4 & $2.41(0.66-8.87)$ & - NS & $2.09(0.58-7.51)$ & - \\
\hline \multicolumn{5}{|c|}{ Time -to-tx interval (months) } \\
\hline$<12$ & 1.00 & 1.00 & 1.00 & 1.00 \\
\hline$>12$ & $2.45(1.23-4.87)$ & $2.51(1.27-4.99)$ & $2.78(1.39-5.54)$ & $2.80(1.39-5.63)$ \\
\hline \multicolumn{5}{|c|}{ Conditioning regimen } \\
\hline Myeloablative & 1.00 & - NS & 1.00 & - \\
\hline Nonmyeloablative & $1.04(0.50-2.15)$ & - NS & $1.02(0.50-2.11)$ & - \\
\hline \multicolumn{5}{|l|}{ HLA match } \\
\hline Full match & 1.00 & 1.00 & 1.00 & 1.00 \\
\hline$\geq 1$ mismatch & $2.48(1.10-5.58)$ & $2.69(1.19-6.04)$ & $2.61(1.16-5.88)$ & $2.81(1.22-6.44)$ \\
\hline $\mathrm{CD}^{2} 4^{+}\left(10^{6} / \mathrm{kg}\right)$ & $0.96(0.80-1.15)$ & $-\mathrm{NS}$ & $0.97(0.81-1.15)$ & - \\
\hline
\end{tabular}

thy and liver fibrosis before the introduction of iron chelation therapy [22]. Nevertheless, in our patients, the major cause of death in the high-ferritin group (ferritin $\geq 1000 \mathrm{ng} / \mathrm{mL}$ ) was infection, the most prevalent form of which was pneumonia. It should be emphasized that patients who undergo alloHSCT are more susceptible to infections than patients receiving transfusions. This is because of prolonged neutropenia and breaks in the mucocutaneous barrier as a result of conditioning regimens, immunity defects and dysfunctions in the reticuloendothelial system [23].

Estimating the role of iron overload on GVHD, our results showed that the difference among groups for acute or chronic GVHD was not statistically significant. This was consistent with the findings of Armand et al [24]. Nevertheless; in a study performed by Mahindra et al [25], in patients with alloHSCT, it was shown that patients with a ferritin level $>1910 \mathrm{ng} / \mathrm{ml}$ had a lower incidence of acute and chronic GVHD. This may be explained by the immunosuppressive role of iron overload as a result of reduced $\mathrm{CD}^{+} \mathrm{T}$-cell counts [26]. Contrary to these findings, a study by Pullarkat et al.[27] found that the patients in high-ferritin group (ferritin $>1000 \mathrm{ng} / \mathrm{ml}$ ) had an increased risk of acute GVHD in patients with HSCT.

In our study, time-to-transplant interval was found to be an important predictor of overall survival (OS) and disease-free survival (DFS). This may be due to earlier remission of some patients as a result of first or second-line chemotherapy regimens. It should be noted that chemoresistant patients underwent alloHSCT later than patients who achieved remission in first-line regimens. Patients who underwent alloHSCT in the early group $(<12$ months) survived longer than patients in the late group (>12 months). This difference was statistically significant for both OS and DFS ( $\mathrm{p}=0.002$ and $\mathrm{p}=0.008$ respectively).

Our study had several limitations. 1) This study was performed retrospectively in a single-center university hospital. It was difficult to determine the causes of death, infections and some other parameters such as albumin and ferritin. Therefore, further multicenter studies may provide further data regarding the association between iron status and transplant outcomes. 2) It is well known that serum ferritin is an acute phase reactant and is not a reliable indicator of total body iron 
stores in patients with inflammation or infections. Therefore, albumin, which is a negative acute phase reactant, was included in the analysis $[28,29]$ and there was no statistical significance between ferritin groups. However, serum ferritin level remains the most cost-effective, inexpensive and noninvasive measure for iron overload available worldwide [30,31]. It is important to estimate the significance of iron overload in patients who underwent alloHSCT using non-invasive imaging like liverspecific MRI.

This study showed that patients with elevated ferritin levels in the pretransplant period had poor survival due to especially infections in alloHSCT. It seems very important for physicians to take iron status into account for probable adverse effects on survival and prognosis in patients candidate for alloHSCT. This hyperferritinemia status may be treated with iron chelation and/or phlebotomy to achieve beter survival and outcomes in alloHSCT. We recently showed that oral deferasirox treatment in the posttransplant period for alloHSCT recipients is safe and effective way of iron chelation [32]. Such further studies will be helpful to confirm our findings.

\section{References}

[1] VAN KRAAİJ MGJ, VERDONCK LF, ROZENBERG-ARSKA M, DEKKER AW. Early infections in adults undergoing matched related and marched unrelated/mismatched donor stem cell transplantation: a comparison of incidence. Bone Marrow Transplant. 2002; 30: 303-309. http://dx.doi. org/10.1038/sj.bmt.1703643

[2] WİLİAMSON EC, MİLLAR MR, STEWARD CG, CORNİSH $\mathrm{JM}$, FOOT AB et al. Infections in adults undergoing unrelated donor bone marrow transplantation. Br J Haematol. 1999; 104: 560-568. http://dx.doi.org/10.1046/j.1365-2141.1999.01229.x

[3] MAJHAİL NS, LAZARUS HM, BURNS JL. Iron overload in hematopoietic cell transplantation. Bone Marrow Transplant. 2008; 41: 997-1003.

[4] LEE JW, KANG HJ, KİM EK, KİM H, SHİN HY et al. Effect of iron overload and iron-chelating therapy on allogeneic hematopoietic SCT in children. Bone Marrow Transplant. 2009; 44: 793-797. http://dx.doi.org/10.1038/bmt.2009.88

[5] Z.Y. LİM, V. FİACCADORİ, S. GANDHİ, J. HAYDEN, M. KENYON, R et al. Impact of pre-transplant serum ferritin on outcomes of patients with myelodysplastic syndromes or secondary acute myeloid leukaemia receiving reduced intensity conditioning allogeneic haematopoietic stem cell transplantation. Leukemia Research. 2010; 34: 723-727. http://dx.doi. org/10.1016/j.leukres.2009.10.028

[6] ARMAND P, KİM HT, RHODES J, SAİNVİL MM, CUTLER $\mathrm{C}$ et al. Iron overload in patients with acute leukemia or MDS undergoing myeloablative stem cell transplantation. Biol Blood Marrow Transplant. 2011; 17: 852-60. http://dx.doi. org/10.1016/j.bbmt.2010.09.006

[7] STRASSER SI, KOWDLEY KV, SALE GE, MCDONALD GB. Iron overload in bone marrow transplant recipients. Bone Marrow Transplant. 1998; 22: 167-173. http://dx.doi. org/10.1038/sj.bmt.1701301
[8] MCKAY PJ, MURPHY JA, CAMERON S, BURNETT AK, CAMPBELL $M$ et al. Iron overload and liver dysfunction after allogeneic or autologous bone marrow transplantation. Bone Marrow Transplant.1996; 17: 63-66.

[9] GORDON LI, BROWN SG, TALLMAN MS, RADEMAKER AW, WEITZZMAN SA et al. Sequential changes in serum iron and ferritin in patients undergoing high dose chemotherapy and radiation with autologous bone marrow transplantation: possible implications for treatment related toxicity. Free Rad Biol Med.1995; 18: 383-389. http://dx.doi.org/10.1016/08915849(94)E0145-9

[10] BUTT NM, CLARK RE: Autografting as a risk factor for persisting iron overload in long-term survivors of acute myeloid leukaemia. Bone Marrow Transplant. 2003; 32: 909-913. http://dx.doi.org/10.1038/sj.bmt.1704244

[11] PRZEPIORKA D, WEISDORFD, MARTIN P, KLINGEMANN HG, BEATTY P et al 1994 Consensus Conference on Acute GVHD Grading. Bone Marrow Transplant.1995; 15: 825828.

[12] PETRIKKKOS G, DROGARİ-APIRANTHİTOU M. Zygomycosis in Immunocompromised non-Haematological Patients. Mediterr J Hematol Infect Dis. 2011; 3: 2011-2012.

[13] ALTES A, REMACHA AF, SARDA P, BAİGET M, SUREDA A et al. Early clinical impact of iron overload in stem cell transplantation. A prospective study. Ann Hematol. 2007; 86: 443-447. http://dx.doi.org/10.1007/s00277-007-0266-X

[14] IGLESİAS-OSMA C, GONZALEZ-VİLLARON L, SAN MİGUEL JF, CABALLERO MD, VAZQUEZ L, DE CASTRO $S$. Iron metabolism and fungal infections in patients with haematological malignancies. J Clin Pathol. 1995;48:223-225. http://dx.doi.org/10.1136/jcp.48.3.223

[15] ALTĖS A, REMACHA AF, SUREDA A, MARTINO R, BRİONES $J$ et al. Iron overload might increase transplantrelated mortality in haematopoietic stem cell transplantation. Bone Marrow Transplant. 2002; 29: 987-989. http://dx.doi. org/10.1038/sj.bmt.1703570

[16] ALTES A, REMACHA AF, SARDA P, SANCHO FJ, SUREDA A et al. Frequent severe liver iron overload after stem cell transplantation and its possible association with invasive aspergillosis. Bone Marrow Transplant. 2004; 34: 505-509. http://dx.doi.org/10.1038/sj.bmt.1704628

[17] EVENS AM, MEHTA J, GORDON LI. Rust and corrosion in hematopoietic stem cell transplantation: the problem of iron and oxidative stress. Bone Marrow Transplant. 2004; 34: 561-71. http://dx.doi.org/10.1038/sj.bmt.1704591

[18] MAERTENS J, DEMUYNCK H, VERBEKEN EK, ZACHÉE $\mathrm{P}$, VERHOEF GE et al. Mucormycosis in allogeneic bone marrow transplant recipients: report of five cases and review of the role of iron overload in the pathogenesis. Bone Marrow Transplant. 1999; 24: 307-312. http://dx.doi.org/10.1038/ sj.bmt. 1701885

[19] KATAOKA K, NANNYA Y, HANGAİSHİ A, IMAİ Y, CHİBA $S$ et al. Influence of pretransplantation serum ferritin on nonrelapse mortality after myeloablative and nonmyeloablative allogeneic hematopoietic stem cell transplantation. Biol Blood Marrow Transplant. 2009; 15: 195-204. http://dx.doi. org/10.1016/j.bbmt.2008.11.012 
[20] BULLEN JJ, ROGERS HJ, SPALDING PB, WARD CG. Natural resistance, iron and infection: a challenge for clinical medicine. J Med Microbiol. 2006; 55: 251-258. http://dx.doi. org/10.1099/jmm.0.46386-0

[21] BULLEN, J. J., SPALDING, P. B., WARD, C. G. \& ROGERS, $\mathrm{H}$. J. The role of $\mathrm{Eh}, \mathrm{pH}$, and iron in the bactericidal power of human plasma. FEMS Microbiol Lett. 1992; 73; 47-52. http://dx.doi.org/10.1111/j.1574-6968.1992.tb05287.x

[22] OLİVİERİ NF, NATHAN DG, MACMÍLLAN JH, WAYNE AS, LIU PP et al.Survival in medically treated patients with homozygous beta-thalassemia. N Engl J Med. 1994; 331: 574578. http://dx.doi.org/10.1056/NEJM199409013310903

[23] DYKEWİCZ CA. Summary of the Guidelines for Preventing Opportunistic Infections among Hematopoietic Stem Cell Transplant Recipients. Clin Infect Dis. 2001; 33: 139-144. http://dx.doi.org/10.1086/321805

[24] ARMAND P, KİM HT, CUTLER CS, HO VT, KORETH J et al. Prognostic impact of elevated pretransplantation serum ferritin in patients undergoing myeloablative stem cell transplantation. Blood. 2007; 109: 4586-4588. http://dx.doi. org/10.1182/blood-2006-10-054924

[25] MAHINDRA A, BOLWELL B, SOBECKS R, RYBİCKİ L, POHLMAN B et al. Elevated pretransplant ferritin is associated with a lower incidence of chronic graft-versus-host disease and inferior survival after myeloablative allogeneic haematopoietic stem cell transplantation. Br J Haematol. 2009; 146: 310-316. http://dx.doi.org/10.1111/j.1365-2141.2009.07774.x

[26] CUNNINGHAM-RUNDLES S, GİARDINA PJ, GRADY RW, CALİFANO C, MCKENZIE P et al. Effect of transfusional iron overload on immune response. J Infect Dis. 2000; 182 Suppl 1: 115-121. http://dx.doi.org/10.1086/315919
[27] PULLARKAT V, BLANCHARD S, TEGTMEİER B, DAGİS A PATANE K et al. Iron overload adversely affects outcome of allogeneic hematopoietic cell transplantation. Bone Marrow Transplant 2008; 42: 799-805. http://dx.doi.org/10.1038/ bmt.2008.262

[28] GABAY C, KUSHNER I. Acute-phase proteins and other systemic responses to inflammation. N Engl J Med. 1999; 340: 448-454. http://dx.doi.org/10.1056/ NEJM199902113400607

[29] MOSHAGE HJ, JANSSEN JA, FRANSSEN JH, HAFKENSCHEID JC, YAP SH. Study of the molecular mechanism of decreased liver synthesis of albumin in inflammation.J Clin Invest. 1987; 79: 1635-1641. http://dx.doi. org/10.1172/JCI113000

[30] ANGELUCCİ E, BAROSİ G, CAMASCHELlA C, CAPPELLINII MD, CAZZOLA $\mathrm{M}$ et al. Italian Society of Hematology practice guidelines for the management of iron overload in thalassemia major and related disorders. Haematologica. 2008; 93: 741-752. http://dx.doi.org/10.3324/ $\underline{\text { haematol.12413 }}$

[31] MARSH JC, BALL SE, DARBYSHİRE P, GORDON-SMITTH EC, KEIDAN AJ et al. Oscier D, Roques AW, Yin JA. Guidelines for the diagnosis and management of acquired aplastic anaemia. British Committee for Standards in Haematology. Br J Haematol. 2003; 123(5): 782-801.

[32] SIVGIN S, ESER B, BAHCEBASI S, KAYNAR L, KURNAZ F, UZER E, PALA C, DENIZ K, OZTURK A, CETIN M, UNAL A. Efficacy and safety of oral deferasirox treatment in the posttransplant period for patients who have undergone allogeneic hematopoietic stem cell transplantation (alloHSCT). Ann Hematol. 2011. [Epub ahead of print] 